\title{
The Effects of Uncertainty and Corporate Governance on Firms' Demand for Liquidity
}

\author{
Christopher F Baum* \\ Boston College and DIW Berlin \\ Atreya Chakraborty \\ University of Massachusetts-Boston \\ Liyan Han \\ Beihang University \\ Boyan Liu \\ Beihang University
}

November 12, 2009

\begin{abstract}
We find that U.S. corporations' demand for liquidity is sensitive to two important factors: uncertainty facing the firm and the quality of corporate governance. Following prior research, we find that both factors have important influences on firms' cash holdings. Our results also indicate that the interactions between uncertainty and governance measures are significant. From a policy perspective, these new findings indicate both governance and the nature of uncertainty may play an important role in managing liquidity risks. Policy recommendations may not only be limited to changes in financial policy but may also include changes in corporate governance.
\end{abstract}

Keywords: liquidity, demand for cash, uncertainty, governance, Gindex JEL: G32, G34, E32

Running head: Uncertainty, Corporate Governance and Firms' Liquidity

${ }^{*}$ This paper was completed during Boyan Liu's stay as a Visiting Scholar at Boston College, which was financially supported by National Natural Science Foundation of China, No. 70521001, and Research Fund of China Ministry of Education for Ph.D. Development, No. 20050006025. Christopher F Baum gratefully acknowledges financial support from the Fritz Thyssen Foundation. Corresponding author: Christopher F Baum, Department of Economics, Boston College, Chestnut Hill, MA 02467 USA, Tel: 617-552-3673, fax 617-552-2308, e-mail: baum@bc.edu. 


\section{Introduction}

"The increase over the last decade in the amount of cash, as a percent of total assets, for the companies in the Standard 8 Poor's 500-stock index has been steep. One study shows that the average cash ratio doubled from 1998 to 2004 and the median ratio more than tripled, while debt levels fell." ... "In the last 25 years, the speed and scale of globalization have increased sharply. That shift to worldwide markets confronted companies with increased currency risks, political risks and new competition-all adding to the overall risk of doing business." (New York Times, March 4, 2008)

"Stung by the financial crisis, companies are holding more cash-and a greater percentage of assets in cash-than at any time in the past 40 years. In the second quarter, the 500 largest nonfinancial U.S. firms, by total assets, held about \$994 billion in cash and short-term investments, or 9.8\% of their assets, according a Wall Street Journal analysis of corporate filings. That is up from $\$ 846$ billion, or $7.9 \%$ of assets, a year earlier. The trend appears to have continued in the third quarter, despite an improving economy. Of those 500 companies, 248 have reported third-quarter results. Their cash increased to $11.1 \%$ of assets, from 10.1\% in the second quarter." ("Jittery Companies Stash Cash", Wall Street Journal, November 2, 2009)

As noted in the financial press, U.S. nonfinancial firms hold a considerable amount of cash on their balance sheets. Research on the motives for cash holdings finds that the uncertainty facing a firm affects cash holdings. Managers hold cash reserves to better cope with adverse shocks: often referred to as the precautionary motive for holding cash. ${ }^{1}$ Bates et al. (2009) find that the average cash-to-assets ratio for U.S. industrial firms has more than doubled between 1980 and 2006. Their research indicates that this affinity for cash is primarily driven by the precautionary motive - the need for liquidity as their business environment has become more risky — rather than agency considerations.

However, new evidence has emerged that agency considerations are also important to a firm's cash holding decisions. Harford et al. (2008) find that firms with weaker corporate governance (i.e., larger values of the Gompers et al. (2003) Gindex) spend their cash quickly and hold smaller cash reserves. Faleye (2004) finds that that higher cash reserves increase

\footnotetext{
${ }^{1}$ See Opler et al. (1999), Baum et al. (2006), Baum et al. (2008).
} 
the possibility of proxy fights and that incumbent managers are more likely to lose their jobs after such contests.

In this paper we first investigate if U.S. corporations' demand for liquidity is influenced by (i) the degree of uncertainty faced by a firm, and (ii) the quality of corporate governance. Our results indicate that cash holdings increase as a firm faces more risk, while they fall as corporate governance weakens (i.e., as the firm's Gindex increases). These results are generally consistent with previous findings and robust over various measures of governance.

After considering these factors' separate effects, we then allow for interactions between the measures of uncertainty and the index of corporate governance to determine whether they influence cash holdings. Our findings highlight how changes in uncertainty affect cash holdings for firms that operate under different regimes of governance. ${ }^{2}$ We find that there are meaningful interactions between uncertainty faced by the firm and its governance structure, leading to bias in models that only consider these factors separately. Such considerations are all the more relevant in light of our findings that the interaction between uncertainty and governance depends on the nature of uncertainty.

Previous research on the role of uncertainty on cash holdings provides clues for our research questions. The agency cost literature, for example, points to asymmetry of information between investors and managers as the key to excess cash holdings (Jensen (1986), Stulz (1990)). As uncertainty within which a firm operates increases, entrenched managers are better positioned to use the resources of the firm for their personal interests. In those times, it is more difficult for investors to monitor their actions or estimate the true value of their investment decisions. This implies that managers of firms with weaker governance will be able to hold more cash as firm-specific uncertainty increases.

As mentioned above, agency costs are not the only motivation for firms to hold cash. Given the high cost of accessing the debt market, firms hold cash to reduce their liquidity risks, particularly in uncertain times. Recent findings indicate that bondholders view

\footnotetext{
${ }^{2} \mathrm{~A}$ recent work considering interactions of corporate governance with managerial ownership is Agca and Mansi (2008).
} 
antitakeover provisions favorably. This is consistent with the view that even a valueincreasing takeover may result in wealth transfer from bondholders to stockholders (Shleifer and Summers (1988), Levene (1960), Warga and Welch (1993)). Consistent with this view, Klock et al. (2005) find that "firms with strongest management rights are associated with a lower cost of debt financing (about fifteen basis points), while firms with strongest shareholders rights are associated with a higher cost of debt financing (about eighteen basis points) after controlling for firm and security specific characteristics." (p. 696). This finding implies that firms with weaker governance will hold less cash in response to increased uncertainty: particularly macroeconomic uncertainty that affects the general availability of credit.

The above discussion suggests that how a firm adjusts its liquidity position in response to uncertainty is ultimately an empirical issue. Depending on the sources of uncertainty and the governance structure of the firm, a firm might increase or decrease its cash holdings when faced with heightened uncertainty. If indeed both agency considerations and precautionary motives affect cash-holding decisions, how do managers balance shareholders' precautionary interests with their own personal (agency) considerations?

We find that faced with a similar increase in firm-specific risk, a firm with weaker corporate governance tends to increase cash reserves, while better-governed firms reduce their cash reserves. The results are quite different when we consider macroeconomic uncertainty. Firms with weaker governance tend to reduce their cash holdings in response to such risks, while better-governed firms decrease their cash holdings. These findings are consistent with earlier results that higher agency costs leads to excess cash holdings, and firms with more antitakeover provisions may be able to borrow at a lower rate and perhaps require lower cash reserves in more uncertain times.

Our findings extend the previous work in two primary ways. Empirical findings on the role of governance and uncertainty, which are generally recognized separately, may be incomplete if they do not explicitly account for the interaction between these factors. We find the interaction between these factors to be statistically significant, robust and 
dependent on the source of uncertainty. This is the primary focus of our research.

These findings also add an interesting new dimension for policy makers and practitioners by highlighting the role of corporate governance. Recommendations on prudent financial risk management policy should consider both the source of uncertainty and the incentive structure under which those recommendations will be executed. Changes in corporate governance may complement and strengthen risk management practices as firms prepare to operate in an increasingly uncertain financial environment in the aftermath of the recent financial crisis.

To address these issues, we first review both strands of the relevant literature. In Section 3, we present a stylized model of a nonfinancial firm's cash holding behavior. In the empirical implementation, we augment this model of cash holdings under uncertainty with a measures of corporate governance, and allow for interactions between uncertainty and governance indicators. Our empirical findings are presented in Section 4 and Section 5 offers concluding remarks.

\section{Cash holdings, uncertainty, and corporate governance}

Recent research (for instance, Ozkan and Ozkan (2004) and the references therein) has emphasized the importance of firm-specific characteristics as a determinant of firms' cashholding behavior. However, the macroeconomic environment within which firms operate could be an equally important determinant of their demand for liquidity. Uncertainty about the macroeconomy may be only one of several sources of uncertainty facing the firm and influencing managers' demand for liquidity. Firm-specific uncertainty may also play an important role in this relationship.

Among firms' characteristics, increasing scrutiny has been focused on measures of corporate governance. Firm-level studies of many aspects of corporate behavior have found that various governance indicators play an important role in managers' decision-making. The effect of governance indicators on firms' cash holdings has recently been carefully examined by Harford et al. (2008), who arrive at some novel findings about this relationship. 
In this section of the paper, we discuss relevant aspects of these two strands of literature and motivate our study in which they are intertwined.

\subsection{The effects of uncertainty on cash holding behavior}

It is well known that some nonfinancial corporations hold significant amounts of cash equaling a considerable fraction of their annual turnover: in many cases, exceeding their indebtedness. ${ }^{3,4}$ Why do firms hold such a significant fraction of their assets in the form of cash? There has been extensive literature on corporate cash holding, going back to Keynes (1936). He suggests three major motives for cash holdings: (i) the transactions motive, (ii) the precautionary motive and (iii) the speculative motive. In general, a firm will hold cash to meet its transaction needs that would arise in the course of carrying out its daily business activities. The precautionary motive requires that a firm will accumulate cash to meet its unanticipated contingencies that may arise, while the speculative motive argues that a firm will accumulate cash to take advantage of profit-making opportunities that may develop. ${ }^{5}$

Focusing on macroeconomic shocks, Cummins and Nyman (2004) demonstrate that firms facing a fixed cost of acquiring external finance in an uncertain environment will hold cash as a buffer against the need to borrow in later periods. Graham and Harvey (2001b) emphasize the importance of financial flexibility (having enough internal financing sources) when managers make financing decisions to avoid curtailing their business activities in response to macroeconomic shocks. However, if the firm's cash flow is subject to macroeconomic shocks, the optimal amount of cash holdings will crucially depend on the manager's perception of firm-specific information through the veil of macroeconomic disturbances. Given that all managers are faced with a similar problem to a greater or

\footnotetext{
${ }^{3}$ This section borrows heavily from Baum et al. (2008).

${ }^{4}$ See Bates et al. (2009).

${ }^{5}$ One would expect stronger motives for corporate cash holdings to appear in imperfect financial markets where external finance involves a high premium. Adverse selection and moral hazard problems stemming from information asymmetry between lenders and borrowers would lead to costly external financing. Thus, firms - particularly those facing a high degree of informational asymmetry — would tend to accumulate more cash to avoid high costs of external finance.
} 
lesser degree, adjustments in liquid assets in response to variations in the macroeconomic environment will in turn generate predictable variations in the cross-sectional distribution of corporate cash holdings. This approach leads to a model linking variations in uncertainty to the distribution of firms' cash-to-asset ratios, but does not make predictions about individual firms' choices.

Firms may react not only to variations in macroeconomic uncertainty but also to uncertainty affecting their industry or merely their firm (firm-level uncertainty). In the approach taken by Baum et al. (2008), both sources of uncertainty are considered in a dynamic model of individual firms' behavior. Their model is motivated by a simple two-period cash bufferstock model in which managers choose the level of liquidity to maximize the expected value of the firm. In estimating this model over a 30,000 firm-quarter sample of US nonfinancial firms and a number of subsamples, the authors find strong support for the hypothesis that increases in either firm-level and macroeconomic uncertainty will cause managers to increase their firms' cash-to-asset ratios.

\subsection{The effects of corporate governance on cash holding behavior}

Cash clearly provides value-increasing flexibility but can easily be used to serve managerial interests. In countries with stronger shareholder rights, firms appear to have lower cash holdings. ${ }^{6}$ However, it is not possible to predict a priori how governance at the firm level should affect cash holdings. Harford et al. (2008) provide some recent empirical evidence on this issue. They find that firms with weaker corporate governance keep smaller cash reserves. Our results support their findings.

Excess cash holding by self-interested managers can insulate them from the disciplines of the capital market (Jensen (1986)). An entrenched manager may then find various ways to increase consumption of perquisites. Relying on internally generated funds enables greater autonomy, and lack of oversight from the capital market allow these managers to engage in value-destroying investments. ${ }^{7}$

\footnotetext{
${ }^{6}$ See Dittmar and Servaes (2003), Pinkowitz et al. (2003)).

${ }^{7}$ See Lang et al. (1991), Blanchard et al. (1994) and Harford (1999)).
} 
A manager's desire to hoard cash from an agency perspective looks attractive. Cash also serve as a good takeover deterrent. Cash allows easy access to some well-proven defenses such as repurchasing stocks, paying greenmail, acquiring a potential bidder or purchasing a related firm that causes a takeover to fail on antitrust grounds. Empirical evidence on the success of such strategies is well documented (Bagwell (1991), Stulz (1988), Dann and DeAngelo (1988)).

However even for the self-serving manager, there are costs to holding significant cash reserves. Excess cash attracts proxy contests that usually result in the incumbent management getting replaced. Faleye (2004), for example, points out that moving from the first to the third quartile of excess cash increases the probability of a proxy fight by $39 \%$.

Both Harford et al. (2008) and Faleye (2004) find that there are significant disciplinary costs for management if they accumulate excess cash reserves. This insight is important to our research. Entrenched management will perhaps be personally better off if they err towards accumulating lower cash reserves. We find that firms with poorer governance (i.e., with a more entrenched management) hold lower cash reserves. In situations where holding higher cash reserves may be in shareholders' interests, managers in weakly-governed firms are likely to choose lower than optimal reserves. Yun (2009) analyses the choice between cash holdings and lines of credit in the context of changes in anti-takeover laws. He finds that firms "increase cash relative to lines of credit when the threat of takeover weakens" (p. 1447), illustrating managers' preferences for greater flexibility in their actions, whether or not they are in shareholders' interests.

Agency costs are not observable, but it may be possible to evaluate the quality of corporate governance in a hedonic sense by considering a number of firm characteristics. This is the approach taken by Gompers et al. (2003) in forming their Gindex measure of the quality of governance. The Gindex is a broad index of antitakeover provisions that influence the likelihood that managers will be able to insulate themselves from the risk of takeover. The 24 provisions, categorized in five groups (delay, protection, voting, state and other provisions) are noted by their presence or absence. The Gindex is then measured on 
a scale of 0 to 24 , with higher values indicating greater power in the hands of managers and higher agency costs. Harford et al. (2008) find that the Gindex is

"... related to the economic fundamentals of the firm and its decision making. Gompers et al. (2003) and Core et al. (2006) document that firms with a large number of antitakeover provisions have lower operating performance compared to those with a small number of provisions. ... Masulis et al. (2007) find that the GIndex is related to stockholder reaction of merger announcements, with high GIndex firms suffering larger losses on the announcement of a takeover attempt. John and Litov (2008) find that firms with large antitakeover provisions have higher debt ratios than those with low provisions, while John and Knyazeva (2006) find that the GIndex is related to firm payout policy." (p. 7)

Thus, we consider that the Gindex is a reasonable measure of the quality of corporate governance, with low values signifying strong shareholders' rights, and high values indicative of agency costs.

\section{Modeling firms' cash holding behavior}

We test the hypotheses that both uncertainty and corporate governance have important effects on nonfinancial firms' cash holding behavior by extending the model of Baum et al. (2008). Our specification is largely similar to that model, with the addition of terms representing corporate governance indices as well as the interaction of an uncertainty measure and corporate governance index to allow for their effects to vary over the range of the other variable.

A challenge to any study considering the effects of uncertainty on firms' behavior is the construction of an appropriate proxy for each type of uncertainty. The next subsections describe our econometric model specification, the strategy in generating proxies for macroeconomic and firm-level uncertainty.

\subsection{Identifying macroeconomic uncertainty}

In our investigation, as in Driver et al. (2005) and Byrne and Davis (2002), we use a GARCH model to proxy for macroeconomic uncertainty. We believe that this approach is 
more appropriate compared to alternatives such as proxies obtained from moving standard deviations of the macroeconomic series (e.g., Ghosal and Loungani (2000)) or survey-based measures based on the dispersion of forecasts (e.g., Graham and Harvey (2001a), Schmukler et al. (1999)).

We consider a volatility measure derived from changes in the consumer price index (CPI) as a proxy for the macro-level uncertainty that firms face in their financial and production decisions. We build a generalized ARCH $(\operatorname{GARCH}(1,1))$ model for CPI inflation where the mean equation is an autoregression over 1979:3-2006:12, as reported in Table 1. We allow the error term in this equation to be distributed as Student $t$ and estimate the appropriate degrees of freedom for the process. The conditional variance derived from this GARCH model is averaged to the annual frequency and then employed in the analysis as our measure of macroeconomic uncertainty.

\subsection{Identifying firm-level uncertainty}

One can employ different proxies to capture firm-specific risk. For instance, Bo and Lensink (2005) use three measures: stock price volatility, estimated as the difference between the highest and the lowest stock price normalized by the lowest price; volatility of sales measured by the coefficient of variation of sales over a seven-year window; and the volatility of number of employees estimated similarly to volatility of sales. Bo (2002) employs a slightly different approach, setting up the forecasting $\operatorname{AR}(1)$ equation for the underlying uncertainty variable driven by sales and interest rates. The unpredictable part of the fluctuations, the estimated residuals, are obtained from that equation and their three-year moving average standard deviation is computed. Kalckreuth (2000) uses cost and sales uncertainty measures, regressing operating costs on sales. The three-month aggregated orthogonal residuals from that regression are used as uncertainty measures.

In contrast to the studies cited above, In contrast to the studies cited above, we proxy firm-level uncertainty at the annual frequency by computing the standard deviation of the firm's excess returns over the market return. Firm returns are calculated using monthly 
equities prices from CRSP, while the market return is monthly value-weighted return including distributions (vwretd) from CRSP.

To ascertain that the measure captured by this method is different from that used to proxy macroeconomic uncertainty, we compute the correlations between the two measures as 0.115. Therefore, the macroeconomic and firm-level measures uncertainty are only weakly correlated.

\subsection{Data}

For the empirical investigation we work primarily with Standard \& Poor's Annual Industrial COMPUSTAT database, 1990-2007, of U.S. firms and the Investor Responsibility Research Center (IRRC) database. Our estimation sample runs through 2006, as one year of future data is required to implement the model. Following Harford et al. (2008), we exclude corporations with two-digit Standard Industrial Classification (SIC) codes of 49 (regulated industries), 60-69 (financial industries) and 88-99 (government enterprises).

In order to construct firm-specific variables we utilize COMPUSTAT data items Cash and Short-term Investment (data1), Depreciation (data5), Total Assets (data6), Income before Extraordinary Items (data18), Capital Expenditures (data128), Sales (data12) and Operating Income before Depreciation (data13). Cash flow is defined as the sum of Depreciation and Income before Extraordinary Items. A measure of cash-flow shocks, $\psi$, is calculated as the first difference of the ratio of cash flow to total assets.

In order to measure the quality of corporate governance, we use the IRRC database which provides annual data on anti-takeover provisions for the years 1990, 1993, 1995, 1998, 2000, 2002, 2004 and 2006 on anti-takeover provisions. ${ }^{8}$ Following Gompers et al. (2003), we use data from IRRC, filling in the missing years, to construct an annual governance index (Gindex) as a measure of the quality of corporate governance. Although one might be concerned that this measure has little within-firm variation, we find that only $32 \%$ of firms in our estimation sample experience no change in Gindex over the period. In contrast,

\footnotetext{
${ }^{8}$ This expands on the sample used in Harford et al. (2008), who did not consider the 2006 IRRC data.
} 
$34 \%$ of firms have one change and $21 \%$ of firms have two changes, with the remaining firms having multiple changes in Gindex over the period. Although Gindex cannot change every year given its construction, but there is considerable variation in its behavior over time at the firm level.

After merging the COMPUSTAT and IRRC samples and dropping firm-years with missing data, we obtain about 12,200 firm-year observations corresponding to over 1,880 firms' annual characteristics. Descriptive statistics for the annual means of cash-to-asset ratios along with investment and sales to asset ratios and $\psi$ are presented in Table 2. From the means of the sample we see that firms hold almost 12 percent of their total assets in cash, which is in line with earlier research on firms' cash holdings.

\subsection{Model specification}

Our empirical investigation is based on the model specification of Baum et al. (2008). This model develops a two-period cash buffer-stock model in which a firm's manager varies the optimal level of liquid assets in response to macroeconomic and/or firm-level uncertainty. The basic setup of the model is particularly suitable for our exercise to highlight the role of governance. The model assumes that at time $t$ the firm has initial resources $W_{t-1}$ to be distributed between capital investment $\left(I_{t}\right)$ and cash holdings $\left(C_{t}\right)$. Cash holdings may include not only cash itself but also low-yield highly liquid assets such as Treasury bills. Investment is expected to earn a gross return in time $t+1$, denoted $E[R]_{t+1}$. Cash holdings in this model primarily guard against bankruptcy when a firm is faced with adverse shocks and the consequent reduced ability to borrow. The analytical solution for the firm's optimal cash holdings is a nonlinear function of initial resources, the expected gross return on investment, the gross borrowing rate, the distribution of cash shocks $\left(H_{t}\right)$, and the probability of acquiring sufficient credit when bankruptcy threatens. After normalizing cash holdings, debt and investment by total assets and parameterizing the model an econometric model specification for firm $i$ at time $t$ is derived as: 


$$
\begin{aligned}
& \left(\widehat{\frac{C_{i t}}{T A_{i t}}}\right)=\phi_{0}+\phi_{1}\left(\frac{\widehat{C_{i t-1}}}{T A_{i t-1}}\right)+\phi_{2}\left(\frac{\widehat{I_{i t-1}}}{T A_{i t-1}}\right)+\phi_{3}\left(\frac{\widehat{S_{i t+1}}}{T A_{i t+1}}\right)+ \\
& \phi_{4} \operatorname{Lead}_{t-1}+\phi_{5} T B 3_{t-1}+\phi_{6} \hat{\psi}_{t-1}+\phi_{7} \hat{\sigma}_{f, i t-1}^{2}+\phi_{8} \hat{\sigma}_{M, t-1}^{2}+\nu_{i t}
\end{aligned}
$$

$I_{i, t-1}$ is the prior value of capital investment, while $S_{t+1}$ is next period's value of sales (entering from the expected returns on investment). $L e a d_{t-1}$ and $T B 3_{t-1}$ represent last period's values of the index of leading indicators and the Treasury bill rate, $\hat{\psi}_{t-1}$ is the previous period's cash flow shock while $\sigma_{f, i t-1}^{2}, \sigma_{M, t-1}^{2}$ represent firm-level and macroeconomic uncertainty, respectively. In this formulation, parameters $\phi_{7}$ and $\phi_{8}$ represent the effects of firm-level and macroeconomic uncertainty, respectively. In our investigation, we modify this specification to estimate the impact of corporate governance and, more importantly, how a measure of governance interacts with uncertainty to influence firms' cash holding behavior.

\section{Econometric implementation and findings}

Estimates of optimal corporate behavior often suffer from endogeneity problems, and the use of instrumental variables is a possible solution. As Yun (2009) notes, “. . . a firm's state of corporate governance may covary with unobserved heterogeneity such as a firm's unobservable investment opportunities." (p. 1448) The use of instrumental variables techniques and the introduction of a forward-looking variable such as future sales (proxying the expected return on investment) should mitigate these endogeneity problems. We estimate our econometric models using a particular form of instrumental variables: the system dynamic panel data (DPD) estimator of Blundell and Bond (1998). System DPD combines equations in differences of the variables with equations in levels of the variables. In this "system GMM" approach, lagged levels are used as instruments for differenced equations and lagged differences are used as instruments for level equations. The models are estimated using a first difference transformation to remove the individual firm effect, dealing with the unobserved heterogeneity. 
The reliability of our econometric methodology depends crucially on the validity of the instruments used. We verify this with Hansen's $J$ test of overidentifying restrictions, which is asymptotically distributed as $\chi^{2}$ in the number of restrictions. The consistency of estimates also depends on the serial correlation in the error terms. We present test statistics for first-order and second-order serial correlation in the results tables. The errors of a properly specified model will exhibit $A R(1)$, but will not exhibit $A R(2)$.

\subsection{Findings for Gindex}

Table 3 presents our estimates of three forms of the model of firms' cash-to-asset ratios. In the first column, for comparability with Harford et al. (2008) we present a version of Equation 1 in which uncertainty terms are suppressed, but the Gindex is included. We find, as did they, that the Gindex has a significant negative effect on cash holdings. In our specification, this negative relationship appears after we control for the effects of partial adjustment, capital investment, growth opportunities (expected sales), macro factors and cash flow shocks. This result supports the spending hypothesis described above: firms with greater management power (higher Gindex) tend to be less liquid, holding lower levels of cash.

In the second column, we reintroduce the uncertainty terms of Equation 1 in conjunction with the Gindex, using the inflation uncertainty proxy. Both of the uncertainty proxy terms display positive and significant coefficients. This can be taken as support for a precautionary demand for liquidity by the firm's managers, or alternatively as reflecting the real option value of a more uncertain environment, in which managers and shareholders would prefer that the firm have greater flexibility to maneuver. The Gindex term exhibits the same negative effect on cash holdings as in the model of column (1).

Although the model of column (2) provides support for our hypothesis that both uncertainty and corporate governance may have important influences on firms' choice of liquidity, it omits one important notion by assuming that the factors may be considered to have independent effects on firm behavior. Thus, in column (3) we add interactions of Gindex 
with each uncertainty measure to the model. In this formulation, the Gindex term itself is not significant in this equation, but as we discuss in the next subsection, the significance of the interaction effect does not preclude a significant effect of Gindex on cash holdings.

\subsection{Analyzing interaction models}

A key element of our analysis is the consideration of possible interaction effects between uncertainty and corporate governance measures. In the presence of statistically significant interactions, the effect of uncertainty (governance) is moderated by the level of governance (uncertainty), and a model excluding those significant interactions will yield biased and inconsistent estimates of the effect of either factor. Thus, we present summary estimates of the effects of each type of uncertainty and the governance index graphically in Figures 1 and 2. For instance, the summary estimate (or total derivative) for the effects of each type of uncertainty may be computed from

$$
\frac{\partial(C / T A)}{\partial U}=\hat{\beta}_{U}+\hat{\beta}_{U G} \times G^{*}
$$

in point and interval form, where $\hat{\beta}_{U}$ and $\hat{\beta}_{U G}$ refer to the estimated coefficients for the effects of Uncertainty and the interaction of Uncertainty and Governance. $G^{*}$ refers to particular levels of the Governance measure. In the presence of a significant interaction

effect, the effects of uncertainty must be calculated conditional on a particular level of Gindex.

Figure 1 (based on column (3) of Table 3) illustrates that the elasticity of cash holdings with respect to firm-level uncertainty is weakly negative for low levels of Gindex, but clearly positive for high levels of that indicator. In response to heightened firm risk, we predict that managers of firms with weak shareholder rights will build up their cash reserves significantly while well-governed firms reduce their cash holdings. This is consistent with the agency motives of free cash flows. An increase in firm-specific risk increases the asymmetry of information between the management and the shareholders and provides the entrenched manager an opportunity to accumulate excess cash for her own purposes. 
Very well-governed firms make much smaller adjustments to their cash position in this circumstance, and are predicted to reduce cash holdings by a smaller amount.

Figure 2 shows that the effect of macroeconomic uncertainty, derived from the conditional variance of CPI inflation, is significantly positive for low levels of Gindex, but becomes significantly negative at high levels of Gindex. This indicates that the high-Gindex firms that are more protected by antitakeover provisions are predicted to lower their cash holdings in response to heightened macroeconomic uncertainty. As stated above, there is evidence that these firms enjoy lower borrowing rates, as creditors prefer them to firms that are more susceptible to takeovers. Takeovers are usually viewed as adding to stockholders' wealth at the expense of existing bondholders.

Interestingly, this finding is also consistent to one of the rationales put forth by John and Litov (2008) to explain their controversial finding that managers of poorly governed firms prefer more financial leverage. They suggest "...managers whose control is being challenged may use debt to inflate their relative voting rights..." (p. 17), increasing the riskiness of the firm in order to protect their investment in firm-specific human capital. In our context, holding lower precautionary cash balances in the face of higher macroeconomic uncertainty may reflect similar behavior on the part of entrenched managers.

In summary, these results show that while the quality of corporate governance (as proxied by the single factor Gindex) has a distinguishable effect on firms' cash holdings, that effect cannot be calculated in isolation. Ignoring the impacts of macroeconomic and firm-level uncertainty faced by the firm's managers will lead to a biased measure of the overall effect. The effects of governance depend quite markedly on variations in firmlevel and macroeconomic uncertainty, and the effects of firm-level and macroeconomic uncertainty depend on the governance index. Neither factor should be considered in the absence of the other. 


\section{Conclusions}

This study considers the importance of the nonfinancial firm's uncertain environment as well as its quality of governance in determining its managers' choice of liquidity. The existing literature considers the importance of each of these factors, but few studies have considered them in combination. In this research we have demonstrated the importance of considering both factors and, crucially, their interactions. We find broad and substantial evidence of interaction effects between uncertainty and governance, and discuss the rationale for those interactions in terms of the conflicting motives of shareholders' and managers' interests.

Our findings, drawn from a sizable panel dataset of U.S. nonfinancial corporations, support the hypothesis that firms' cash holdings are influenced by the precautionary motive for the demand for money. At the same time, cash holdings differ meaningfully among firms with differing levels of corporate governance or agency costs. When these factors are both included in the model, each has an important role to play, as do their interactions. The presence of statistically significant interaction effects implies that measures of the total effect of a change in firm-level or macroeconomic uncertainty (governance) cannot be properly calculated without taking the existing level of governance (uncertainty measures) into account. When that is done, the importance of both factors in determining firms' levels of cash holdings is evident. 


\section{References}

Agca, S. and Mansi, S.A. (2008) Managerial ownership, takeover defenses and debt financing, Journal of Financial Research, 31, 85-112.

Bagwell, L.S. (1991) Share repurchase and takeover deterrence, RAND Journal of Economics, 22, 72-88.

Bates, T.W., Kahle, K.M., and Stulz, R.M. (2009) Why do U.S. firms hold so much more cash than they used to?, Journal of Finance, 64, 1985-2021.

Baum, C.F., Caglayan, M., Ozkan, N., and Talavera, O. (2006) The impact of macroeconomic uncertainty on non-financial firms' demand for liquidity, Review of Financial Economics, 15, 289-304.

Baum, C.F., Caglayan, M., Stephan, A., and Talavera, O. (2008) Uncertainty determinants of corporate liquidity, Economic Modelling, 25, 833-849.

Blanchard, O.J., Lopez-de Silanes, F., and Shleifer, A. (1994) What do firms do with cash windfalls?, Journal of Financial Economics, 36, 337-360.

Blundell, R. and Bond, S. (1998) Initial conditions and moment restrictions in dynamic panel data models, Journal of Econometrics, 87, 115-143.

Bo, H. (2002) Idiosyncratic uncertainty and firm investment, Australian Economic Papers, 41, 1-14.

Bo, H. and Lensink, R. (2005) Is the investment-uncertainty relationship nonlinear? An empirical analysis for the Netherlands, Economica, 72, 307-331.

Byrne, J.P. and Davis, E.P. (2002) Investment and uncertainty in the G7, Discussion papers, National Institute of Economic Research, London.

Core, J.E., Guay, W.R., and Rusticus, T.O. (2006) Does weak governance cause weak stock returns? An examination of firm operating performance and investors' expectations, Journal of Finance, 61, 655-687.

Cummins, J.G. and Nyman, I. (2004) Optimal investment with fixed financing costs, Finance Research Letters, 1, 226-235.

Dann, L.Y. and DeAngelo, H. (1988) Corporate financial policy and corporate control : A study of defensive adjustments in asset and ownership structure, Journal of Financial Economics, 20, 87-127. 
Dittmar, Amy J.M.S. and Servaes, H. (2003) International corporate governance and corporate cash holdings, Journal of Financial and Quantitative Analysis, 38:1, 111-33.

Driver, C., Temple, P., and Urga, G. (2005) Profitability, capacity, and uncertainty: A model of UK manufacturing investment, Oxford Economic Papers, 57, 120-141.

Faleye, O. (2004) Cash and corporate control, Journal of Finance, 59, 2041-2060.

Ghosal, V. and Loungani, P. (2000) The differential impact of uncertainty on investment in small and large business, The Review of Economics and Statistics, 82, 338-349.

Gompers, P.A., Ishii, J., and Metrick, A. (2003) Corporate governance and equity prices, Quarterly Journal of Economics, 118, 107-155.

Graham, J.R. and Harvey, C.R. (2001a) Expectations of equity risk premia, volatility and asymmetry from a corporate finance perspective, NBER Working Papers 8678, National Bureau of Economic Research, Inc.

Graham, J.R. and Harvey, C.R. (2001b) The theory and practice of corporate finance: Evidence from the field, Journal of Financial Economics, 60, 187-243.

Harford, J. (1999) Corporate cash reserves and acquisitions, Journal of Finance, 54, 1969-1997.

Harford, J., Mansi, S.A., and Maxwell, W.F. (2008) Corporate governance and firm cash holdings, Journal of Financial Economics, 87, 535-555.

Jensen, M.C. (1986) Agency costs of free cash flow, corporate finance, and takeovers, American Economic Review, 76, 323-29.

John, K. and Knyazeva, A. (2006) Payout policy, agency conflicts, and corporate governance, Working papers, Stern School of Business, New York University.

John, K. and Litov, L. (2008) Corporate governance and financing policy: New evidence, Working papers, Stern School of Business, New York University.

Kalckreuth, U. (2000) Exploring the role of uncertainty for corporate investment decisions in Germany, Discussion Papers 5/00, Deutsche Bundesbank - Economic Research Centre.

Keynes, J.M. (1936) The general theory of employment, interest and money, London, Harcourt Brace.

Klock, M.S., Mansi, S.A., and Maxwell, W.F. (2005) Does corporate governance matter to bondholders?, Journal of Financial and Quantitative Analysis, 40, 693-719. 
Lang, L.H.P., Stulz, R.M., and Walkling, R.A. (1991) A test of the free cash flow hypothesis: The case of bidder returns, Journal of Financial Economics, 29, 315-335.

Levene, H. (1960) Robust tests for equality of variances, in I. Olkin, S. Ghurye, W. Hoeffding, W. Madow, and H. Mann, editors, Contributions to Probability and Statistics: Essays in honor of Harold Hotelling, pages 278-292, Stanford University Press, Menlo Park, CA.

Masulis, R.W., Wang, C., and Xie, F. (2007) Corporate governance and acquirer returns, Journal of Finance, 62, 1851-1889.

Opler, T., Pinkowitz, L., Stulz, R., and Williamson, R. (1999) The determinants and implications of cash holdings, Journal of Financial Economics, 52, 3-46.

Ozkan, A. and Ozkan, N. (2004) Corporate cash holdings: An empirical investigation of UK companies, Journal of Banking and Finance, 28, 2103-2134.

Pinkowitz, L., Stulz, R.M., and Williamson, R. (2003) Do firms in countries with poor protection of investor rights hold more cash?, NBER Working Papers 10188, National Bureau of Economic Research, Inc.

Schmukler, S., Mehrez, G., and Kaufmann, D. (1999) Predicting currency fluctuations and crises - do resident firms have an informational advantage?, Policy Research Working Paper Series 2259, The World Bank.

Shleifer, A. and Summers, L.H. (1988) Breach of trust in hostile takeovers, in A.J. Auerbach, editor, Corporate Takeovers: Causes and Consequences, pages 33-68, National Bureau of Economic Research, Inc., Cambridge, MA.

Stulz, R.M. (1988) Managerial control of voting rights : Financing policies and the market for corporate control, Journal of Financial Economics, 20, 25-54.

Stulz, R.M. (1990) Managerial discretion and optimal financing policies, Journal of Financial Economics, 26, 3-27.

Warga, A. and Welch, I. (1993) Bondholder losses in leveraged buyouts, Review of Financial Studies, 6, 959-82.

Yun, H. (2009) The choice of corporate liquidity and corporate governance, Review of Financial Studies, 22, 1447-1475. 


\section{Elasticity of cash vs. firm-level uncertainty}

Firm-level uncertainty: s.d. of excess returns

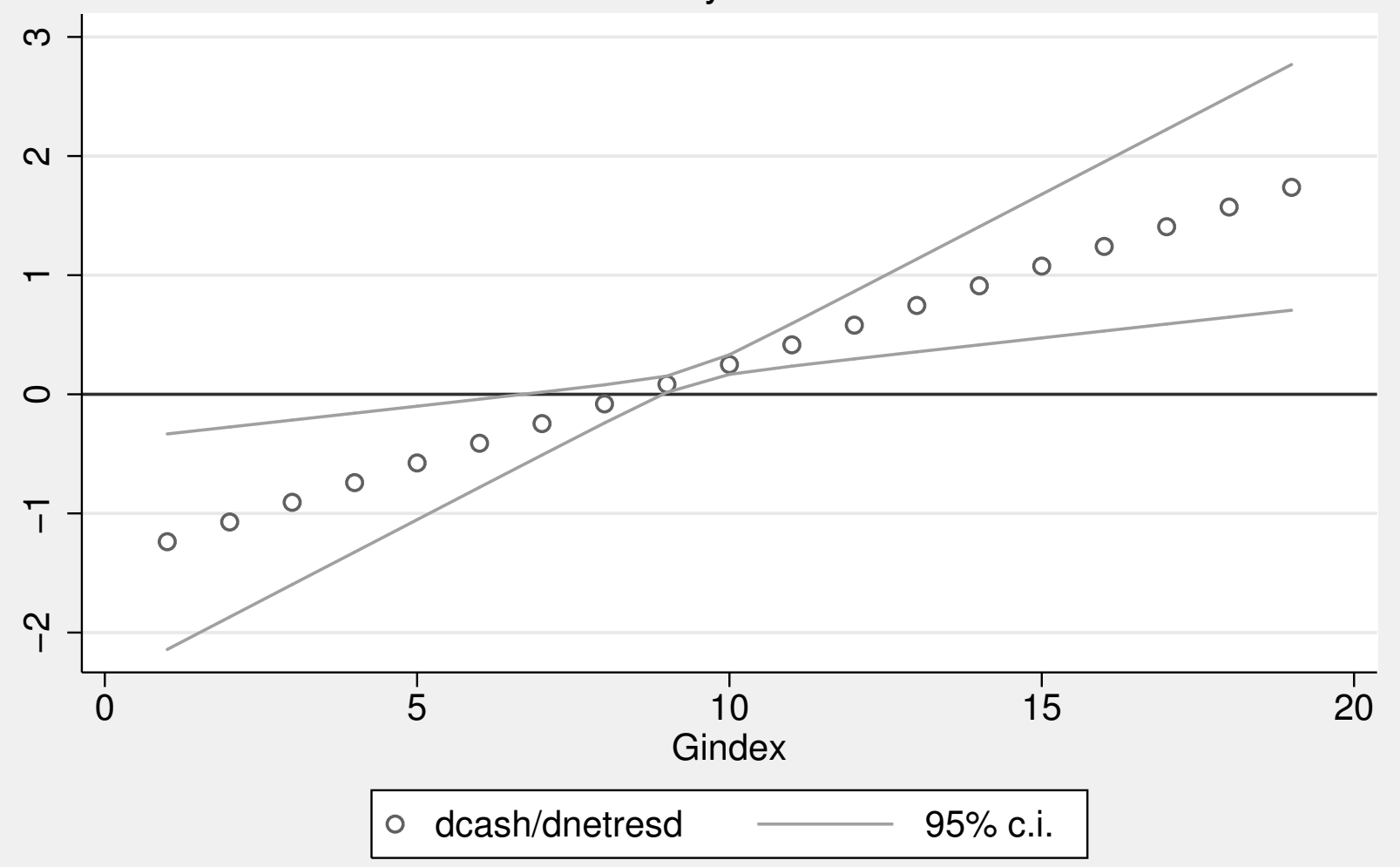

Figure 1: Elasticities for firm-level uncertainty 


\section{Elasticity of cash vs. macroeconomic uncertainty}

Macro uncertainty: inflation

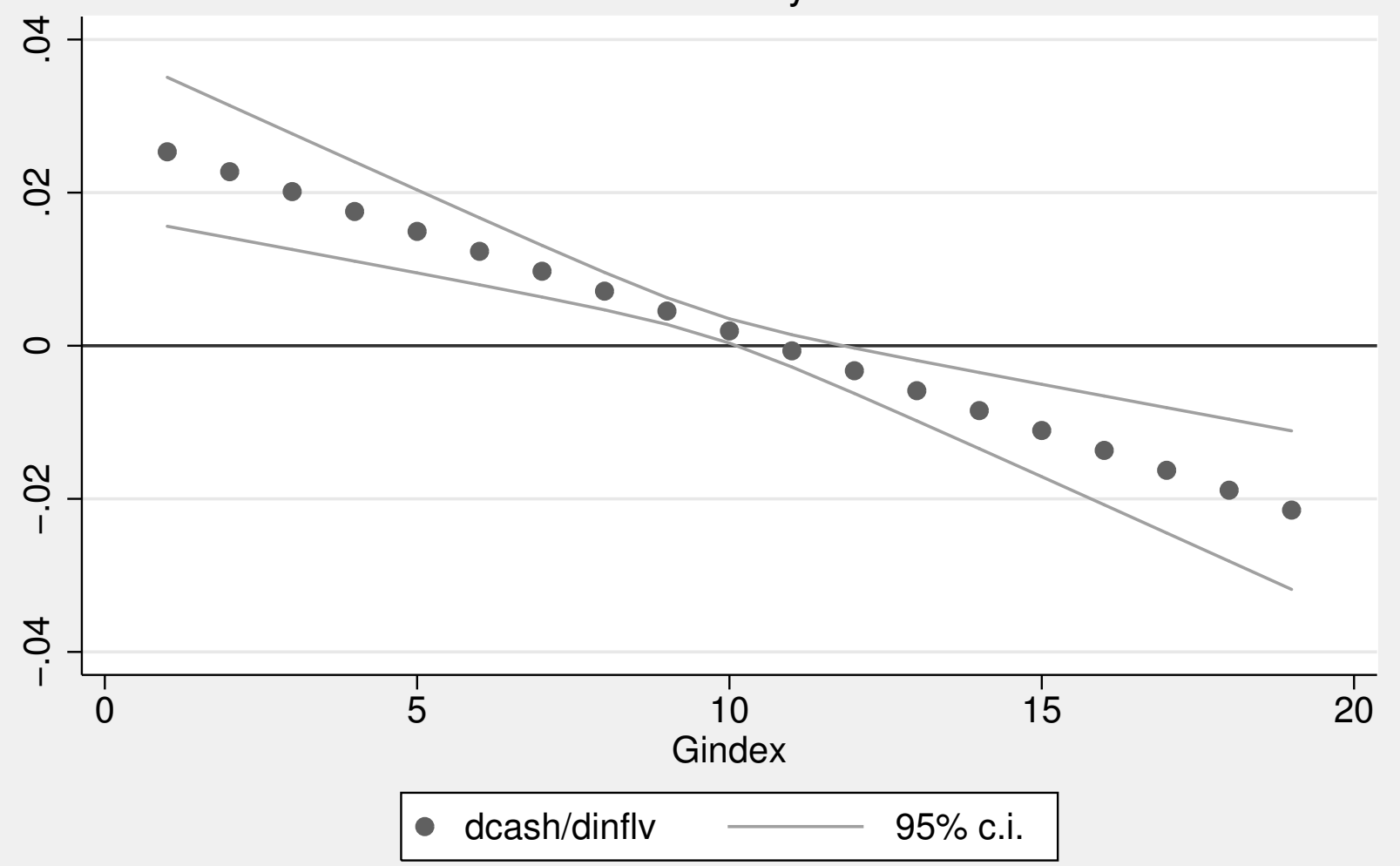

Figure 2: Elasticities for macroeconomic uncertainty 
Table 1: GARCH(1,1) Proxy for Macroeconomic Uncertainty based on CPI Inflation, 1979:3-2006:12

\begin{tabular}{lc}
\hline \hline & $(1)$ \\
& CPI Inflation \\
\hline Inflation $_{t-1}$ & $0.508^{* * *}$ \\
& $(10.664)$ \\
Constant & $0.001^{* * *}$ \\
& $(7.980)$ \\
\hline ARCH $(1)$ & $0.154^{* * *}$ \\
& $(2.739)$ \\
& $0.828^{* * *}$ \\
GARCH(1) & $(15.825)$ \\
& 0.000 \\
Constant & $(1.497)$ \\
\hline$t_{d f}$ & 5.987 \\
& $(2.033)$ \\
\hline Log-likelihood & 1589.257 \\
Observations & 334 \\
\hline \hline$t$ statistics in parentheses \\
$* p<0.10, * * p<0.05, * * * p<0.01$
\end{tabular}

Table 2: Descriptive Statistics, 1990-2006

This table provides summary statistics for selected variables in our sample for firm-years of U.S. corporations. $p 25, p 50$ and $p 75$ are the quartiles of the variables, while $N$ is the number of firm-years available for each category.

\begin{tabular}{lcccccc}
\hline \hline & mean & $\mathrm{sd}$ & $\mathrm{p} 25$ & $\mathrm{p} 50$ & $\mathrm{p} 75$ & $\mathrm{~N}$ \\
\hline Cash/Total Assets & 0.1173 & 0.1492 & 0.0185 & 0.0571 & 0.1551 & 12,241 \\
Investment/Total Assets & 0.0598 & 0.0497 & 0.0272 & 0.0468 & 0.0768 & 12,213 \\
Sales/Total Assets & 1.2127 & 0.7381 & 0.7388 & 1.0636 & 1.5043 & 12,239 \\
Gindex & 9.3329 & 2.7211 & 7.0000 & 9.0000 & 11.0000 & 12,241 \\
Firm Level Uncertainty & 0.0866 & 0.0569 & 0.0537 & 0.0739 & 0.1036 & 12,236 \\
Inflation Uncertainty & 4.1368 & 2.3494 & 2.2165 & 3.3478 & 5.2644 & 12,241 \\
\hline \hline
\end{tabular}




\section{Table 3. Models of Firms' Demand for Cash}

This table presents estimated dynamic models of nonfinancial firms' demand for cash. $C$ is the firm's cash-to-total assets ratio. $I$ is the ratio of capital investment expenditures to total assets. $S$ is the ratio of sales to total assets. Lead is the change in the detrended index of leading indicators, while $T B 3$ is the three-month Treasury bill rate. $\triangle C F$ is the change in the firm's ratio of cash flow to total assets. Gindex is the Gompers et al. (2003) index of corporate governance. $\sigma_{f}^{2}$ is the measure of firm-specific uncertainty, while $\sigma_{I n f l}^{2}$ is the measure of macroeconomic uncertainty derived from inflation. Hansen $\mathrm{J}$ P-value is the $p$-value of the $J$ test of overidentifying restrictions. $A R(1)$ and $A R(2) \mathrm{P}$-values are the tests for significant first-order and second-order serial correlation in the estimated model's residuals. All specifications include a set of year dummies to control for unobserved time-varying effects.

\begin{tabular}{|c|c|c|c|}
\hline & (1) & $(2)$ & (3) \\
\hline \multirow[t]{2}{*}{$C_{t-1}$} & $0.842^{* * *}$ & $0.878^{* * *}$ & $0.818^{* * *}$ \\
\hline & $(23.046)$ & $(81.269)$ & $(70.505)$ \\
\hline \multirow[t]{2}{*}{$I_{t-1}$} & 0.0614 & -0.00694 & -0.0235 \\
\hline & $(0.467)$ & $(-0.567)$ & $(-1.445)$ \\
\hline \multirow[t]{2}{*}{$S_{t+1}$} & 0.000660 & $-0.00279^{* * *}$ & $-0.00588^{* * *}$ \\
\hline & $(0.061)$ & $(-3.731)$ & $(-5.396)$ \\
\hline \multirow[t]{2}{*}{$\operatorname{Lead}_{t-1}$} & $-0.000646^{* * *}$ & $-0.000214^{* *}$ & -0.000124 \\
\hline & $(-2.793)$ & $(-2.250)$ & $(-1.504)$ \\
\hline \multirow[t]{2}{*}{$T B 3_{t-1}$} & 0.00527 & -0.00118 & $-0.00285^{* * *}$ \\
\hline & $(0.989)$ & $(-1.609)$ & $(-4.477)$ \\
\hline \multirow{2}{*}{$\Delta C F_{t-1}$} & -0.0217 & $0.159^{*}$ & 0.00811 \\
\hline & $(-0.410)$ & $(1.727)$ & $(0.101)$ \\
\hline \multirow[t]{2}{*}{ Gindex } & $-0.00446^{* * *}$ & $-0.000555^{* *}$ & -0.00598 \\
\hline & $(-2.829)$ & $(-2.452)$ & $(-1.543)$ \\
\hline \multirow[t]{2}{*}{$\sigma_{f, t-1}^{2}$} & & $0.181^{* *}$ & $-1.402^{* * *}$ \\
\hline & & $(2.056)$ & $(-2.717)$ \\
\hline \multirow[t]{2}{*}{$\sigma_{I n f l, t-1}^{2}$} & & $0.00520^{* * *}$ & $0.0279^{* * *}$ \\
\hline & & $(4.059)$ & $(5.061)$ \\
\hline \multirow[t]{2}{*}{$\sigma_{f, t-1}^{2} \times$ Gindex } & & & $0.165^{* * *}$ \\
\hline & & & $(3.016)$ \\
\hline \multirow[t]{2}{*}{$\sigma_{\text {Infl } l, t-1}^{2} \times$ Gindex } & & & $-0.00260^{* * *}$ \\
\hline & & & $(-4.623)$ \\
\hline \multirow[t]{2}{*}{ Constant } & $0.140^{* * *}$ & $0.0171^{* *}$ & $0.0877^{* *}$ \\
\hline & $(3.658)$ & $(2.178)$ & $(2.395)$ \\
\hline $\mathrm{N}$ of firm-years & 12241 & 12228 & 12228 \\
\hline $\mathrm{N}$ of firms & 1784 & 1781 & 1781 \\
\hline
\end{tabular}




\begin{tabular}{llll} 
Hansen J P-value & 0.4258 & 0.1639 & 0.8763 \\
$\mathrm{AR}(1) \mathrm{P}$-value & 0.0000 & 0.0000 & 0.0000 \\
$\mathrm{AR}(2) \mathrm{P}$-value & 0.1542 & 0.5816 & 0.0973 \\
\hline \hline
\end{tabular}

$t$ statistics in parentheses

${ }^{*} p<0.10,{ }^{* *} p<0.05,{ }^{* * *} p<0.01$ 